\title{
20. COCCOLITH AND SILICOFLAGELLATE STRATIGRAPHY NEAR ANTARCTICA, DEEP SEA DRILLING PROJECT, LEG 28
}

\author{
David Bukry, United States Geological Survey, La Jolla, California
}

\section{INTRODUCTION}

Leg 28 of the Deep Sea Drilling Project, December 1972 to February 1973, through the Southern Ocean from Fremantle, Australia, to Christchurch, New Zealand (Figure 1), recovered 329 cores at 11 drilling sites, Sites 264-274. Light-microscope techniques were used to study the coccoliths and silicoflagellates in smear slides of 122 samples from these cores. Coccolith zonation, summarized in Figure 2, is that of Bukry (1973) and incorporates the Gartnerago obliquum Zone (Roth, 1973) and the Nephrolithus frequens Zone (Cepek and Hay, 1969).

\section{OLIGOCENE SILICOFLAGELLATE STRATIGRAPHY}

Silicoflagellate biostratigraphy of deep-sea sediment is still in the initial phase of data gathering. This is especially true for the Oligocene because of a paucity of silicoflagellate-bearing strata. Although the applicable taxonomy for silicoflagellates has reached detailed and comprehensive levels (Glezer, 1966; Loeblich et al., 1968; Bachmann, 1970; Ling, 1972; Dumitrică, 1973), the stratigraphic distribution of taxa through the Oligocene has only recently become known.

Two significant new Oligocene silicoflagellate-bearing sections were cored at Sites 267 and 274 during Leg 28. Two zones and two subzones are present.

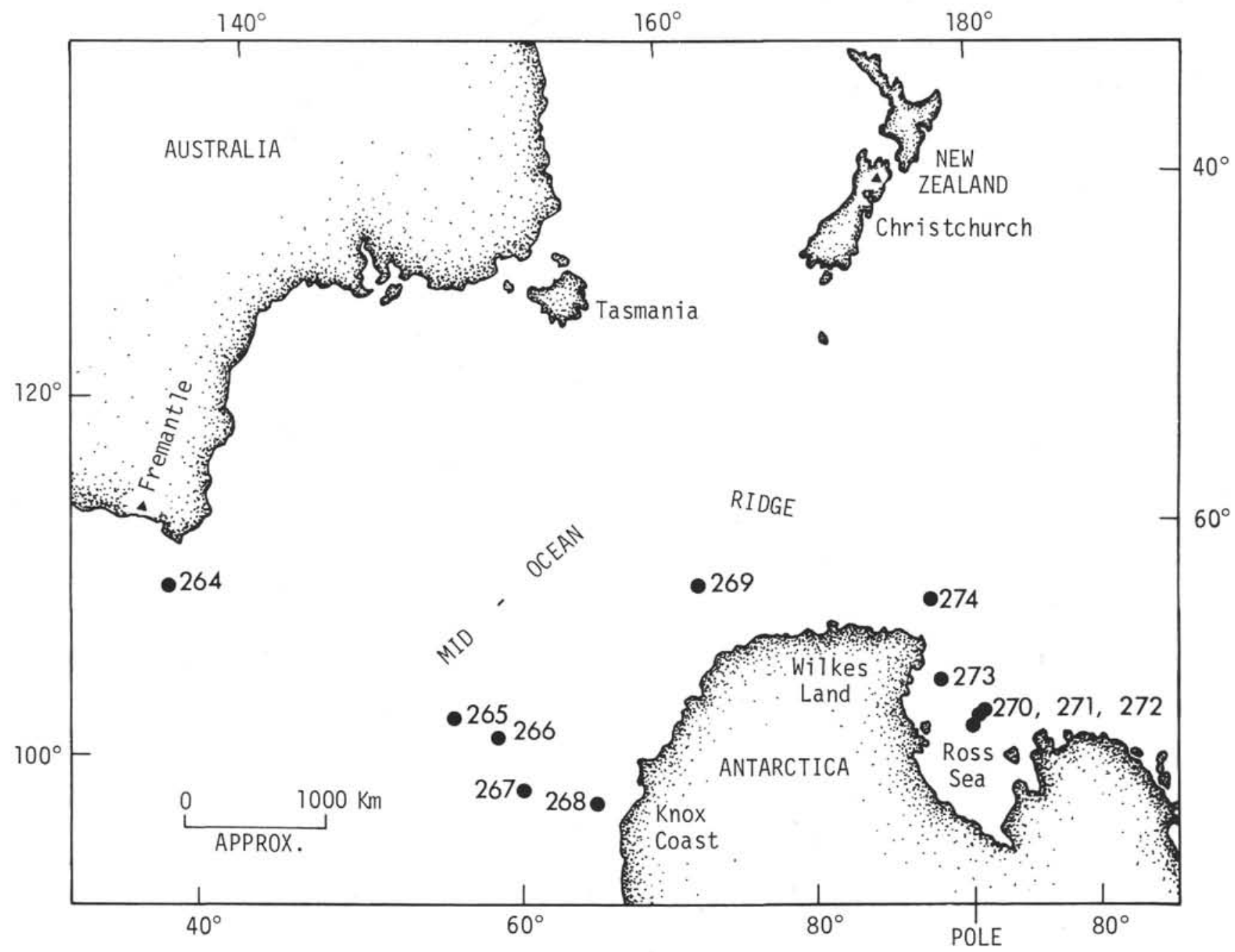

Figure 1. Sketch map showing sites drilled on Deep Sea Drilling Project, Leg 28. 


\begin{tabular}{|c|c|c|c|c|c|c|c|}
\hline \multirow{2}{*}{$\begin{array}{l}\text { Series or } \\
\text { Subseries }\end{array}$} & \multirow[b]{2}{*}{ Zone } & \multirow[b]{2}{*}{ Subzone } & \multicolumn{5}{|c|}{ DSDP Site } \\
\hline & & & 264 & 265 & 266 & 267 & 268 \\
\hline Holocene & \multicolumn{2}{|l|}{ Emiliania huxleyi } & & & & & \\
\hline \multirow{3}{*}{ Pleistocene } & Gephyrocapsa oceanica & & & $2-6$ & & & \\
\hline & \multirow{2}{*}{ Crenalithus doronicoides } & Gephyrocapsa caribbeanica & $1-6$ & \multirow{2}{*}{$7-6$} & & & \\
\hline & & Emiliania anmula & $1 \mathrm{~A}-5$ & & & & \\
\hline \multirow{3}{*}{$\begin{array}{c}\text { Upper } \\
\text { Pliocene }\end{array}$} & \multirow{3}{*}{ Discoaster brouweri } & Cyclococcolithina macintyrei & $2 \mathrm{~A}-2$ & \multirow{11}{*}{$11-1 / 15-4$} & & & \\
\hline & & Discoaster pentaradiatus & & & & & \\
\hline & & Discoaster tamalis & $2-1,2 \mathrm{~A}-6$ & & & & \\
\hline \multirow{4}{*}{$\begin{array}{c}\text { Lower } \\
\text { Pliocene }\end{array}$} & \multirow{2}{*}{ Reticulofenestra pseudoumbilica } & Discoaster as y'mmetricus & & & \multirow{11}{*}{$10-6$} & & \\
\hline & & Sphenolithus neoabies & & & & & \\
\hline & \multirow{3}{*}{ Ceratolithus tricorniculatus } & Ceratolithus rugosus & & & & & \\
\hline & & Ceratolithus acutus & $2-2 / 2-4$ & & & & \\
\hline \multirow{4}{*}{$\begin{array}{c}\text { Upper } \\
\text { Miocene }\end{array}$} & & Triquetrorhabdulus rugosus & & & & & \\
\hline & \multirow{2}{*}{ Discoaster quinqueramus } & Ceratolithus primus & & & & & \\
\hline & & Discoaster berggrenii & & & & & \\
\hline & Discoaster neohamatus & Discoaster neorectus & & & & & \\
\hline & Discouster heomatiantis & Discoaster bellus & & $15-6$ & & & \\
\hline Middle & $\begin{array}{l}\text { Discoaster hamatus } \\
\text { Catinaster coalitus }\end{array}$ & & & & & & \\
\hline Miocene & & & & & & & \\
\hline & Discoaster exilis & $\begin{array}{l}\text { Discoaster kugleri } \\
\text { Coccolithus miopelagicus }\end{array}$ & & $16-3 / 16-6 ?$ & $12-5 / 13-6$ & & \\
\hline & Sphenolithus heteromorphus & & & & $14-4$ & & \\
\hline & Helicopontosphaera ampliaperta & & & & $15-3 / 18-1$ & & \\
\hline Lower & Sphenolithus belemnos & & & & & & \\
\hline Miocene & & Discoaster druggii & & & $18-5 / 23-1$ & & $10-1$ \\
\hline & Triquetrorhabdulus carinatus & Discoaster deflandrei & & & & & \\
\hline & & Cyclicargolithus abisectus & & & & & \\
\hline & Sphenolithus ciperoensis & & & & & $4-2 / 5-1$ & $17-3$ \\
\hline & Sphenolithus distentus & & & & & $4-2 / 5-1$ & $17-3$ \\
\hline Oligocene & Sphenolithus predistentus & & & & & & \\
\hline & & Reticulofenestra hillae & & & & & \\
\hline & Helicopontosphaera reticulata & Coccolithus formosus & & & & $6-1$ & \\
\hline & & Coccolithus subdistichus & & & & & \\
\hline Upper Eocene & Discoaster barbadiensis & & & & & 10B-1 & \\
\hline & & Discoaster saipanensis & $2-4 / 2-6$ & & & & \\
\hline & Reticulofenestra umbilica & Discoaster bifax & $3-6 / 7-4$ & & & & \\
\hline Middle & & Coccolithus staurion & & & & & \\
\hline Eocene & Namnotetrina quadrata & Chiasmolithus gigas & $8-4 / 9-2,3 \mathrm{~A}-5$ & & & & \\
\hline & & Discoaster strictus & & & & & \\
\hline & Discoaster sublodoensis & Rhabdosphaera inflata & $4 A-5$ & & & & \\
\hline & & Discoasteroides kuepperi & $10-3$ & & & & \\
\hline Lower & Discoaster lodoensis & & & & & & \\
\hline Eocene & Tribrachiatus orthostylus & & & & & & \\
\hline & Discoaster diastypus & & & & & & \\
\hline & Discoaster multiradiatus & Campylosphaera eodela & & & & & \\
\hline & Discoaster muatriaciantis & Chiasmolithus bidens & & & & & \\
\hline & Discoaster nobilis & & & & & & \\
\hline Palcocene & Discoaster mohleri & & & & & & \\
\hline & Heliolithus kleinpellii & & & & & & \\
\hline & Fasciculithus ty'mpaniformis & & & & & & \\
\hline & Cruciplacolithus tenuis & & & & & & \\
\hline & Nephrolithus frequens & & & & & & \\
\hline & Lithraphidites quadratus & & & & & & \\
\hline Upper & Tetralithus trifidus & & & & & & \\
\hline Cretaceous & Broinsonia parca & & & & & & \\
\hline & Eiffellithus augustus & & & & & & \\
\hline & Gartnerago obliquum & & $11-1 / 11-2$ & & & & \\
\hline
\end{tabular}

Figure 2. Coccolith zonation of sediment from a transect of the Southeast Indian Ridge from Australia to Antarctica, Leg 28. The numbers assigned to zonal intervals are core and section numbers of samples examined. A core is typically 9.5 meters long; a section is a sixth part of a core, 1.5 meters, both numbered from the top. Where a zone or subzone is represented in samples from two or more core sections, the highest and lowest sections are listed. 
The older section at Site 274 is especially thick, and Oligocene silicoflagellates are recognized in the full range of cores examined, Cores 21 to 34 (192-318 m). Species present throughout the interval include Corbisema apiculata, $C$. hastata $\mathrm{s}$. ampl., Dictyocha deflandrei, Distephanus crux, and Mesocena apiculata (Figure 3 ). The common to abundant occurrence of $D$. deflandrei indicates the Dictyocha deflandrei Zone (Bukry and Foster, 1974), which is present in Hole 280A south of Tasmania and possibly at the Oamaru section in New Zealand (Mandra et al., 1973). The upper part of the section at Site 274 is distinguished by the abundant occurrence of Dictyocha frenguellii. This unusual silicoflagellate has previously been reported only from the USSR in strata considered late Eocene or early Oligocene (Glezer, 1966). No specimens of this species have been reported from the more definitely dated late Eocene or early Oligocene Oamaru section in New Zealand (Mandra et al., 1973), and study of wellcorrelated Eocene deep-sea samples has shown no specimens of D. frenguellii (Ling, 1972; Bukry and Foster, 1974). Therefore, even though Dictyocha frenguellii is structurally analogous to the Eocene species $D$. spinosa, it appears from its stratigraphic distribution at Site 274 to be an exclusively Oligocene form that developed from $D$. deflandrei. The interval characterized by the common occurrence of $D$. frenguellii at Site 274 is designated as the Dictyocha frenguellii Subzone of the Dictyocha deflandrei Zone. The lower part of the $D$. deflandrei Zone at DSDP 274 lacks $D$. frenguellii but has common Mesocena apiculata and is designated the Mesocena apiculata Subzone.

Oligocene assemblages at Site 267 are younger than those at 274. The Naviculopsis biapiculata-Naviculopsis regularis group, recorded as $N$. biapiculata, is predominant in Core 4 . There is little species diversity, a feature noted in the late Oligocene of other areas (Bachmann, 1970; Ling, 1972; Dumitrică, 1973; Bukry and Foster, 1974). The late Oligocene has been indicated by the earliest occurrence and abundance of Rocella gemma. But the samples from Site 267 contain no R. gemma, although the diatom Coscinodiscus vigilans, which in some ways resembles $R$. gemma, is common (see Plate 4). It therefore appears that Naviculopsis is more cosmopolitan and provides a better basis for long-range correlation in the late Oligocene as well as in the early Miocene (Martini, 1972; Dumitricǎ, 1973; Bukry and Foster, 1974). The first significant occurrence of $N$. biapiculata following the decline of Dictyocha deflandrei is used to indicate the base of the Naviculopsis biapiculata Zone in the Antarctic region.

The deepest silicoflagellate sample at Site 267 may indicate a local environmental anomaly or a biostratigraphic unit that is as yet unrecognized elsewhere. Sample $267-5-1,91 \mathrm{~cm}$ is very distinctive in the common occurrence of long-spined Corbisema triacantha and large C. archangelskiana. It has very low abundances of Dictyocha deflandrei, D. frenguellii, and Naviculopsis biapiculata s. ampl., which characterize adjacent zones.

\section{SITE SUMMARIES}

\section{Site 264 (lat $34^{\circ} 58.13^{\prime} \mathrm{S}$, long $112^{\circ} 02.68^{\prime} \mathrm{E}$, depth $2873 \mathrm{~m}$ )}

Site 264 is near the southern edge of the Naturaliste Plateau off southwestern Australia. Cores 1 to 2 (0-35 $\mathrm{m})$ and $1 \mathrm{~A}$ to $2 \mathrm{~A}(9-28 \mathrm{~m})$ range in age from late Miocene to Pleistocene. Placoliths are abundant and moderately etched whereas discoasters are scarce and moderately overgrown. Placolith species Crenalithus doronicoides, Coccolithus pelagicus, Cyclococcolithina leptopora, and C. macintyrei are common to abundant. The array of late Pliocene discoasters present in the Discoaster tamalis Subzone are typical of middle- to low-latitude correlatives: Discoaster asymmetricus, $D$. brouweri, D. pentaradiatus, D. surculus, and D. tamalis. The upper part of Core $2(26-31 \mathrm{~m})$ contains Ceratolithus primus and C. tricorniculatus and is assigned to the latest Miocene or earliest Pliocene. If the absence of birefringent species of Ceratolithus such as $C$. acutus and $C$. rugosus is not a result of paleoecologic conditions, then the assemblage could be assigned to the late Miocene.

A sharp lithologic contact in Section 4 of Core 2 at 31 meters marks the top of a thick middle Eocene sequence $(31-159 \mathrm{~m})$ at this site. Cool-temperate coccolith assemblages are indicated by the abundance of placoliths, the high proportion of Chiasmolithus to Discoaster, the low proportion of rosette- to free-rayed Discoaster specimens, and the paucity of Sphenolithus and Coccolithus formosus (syn. Cyclococcolithina formosa). The rarity of Sphenolithus with respect to Discoaster in this section suggests that, although both genera are most abundant in warm environments, Sphenolithus had lesser tolerance to cooler conditions. This relation might also be inferred from the later extinction pattern of the two genera in the Pliocene; sphenoliths disappeared prior to discoasters during an interval of declining temperature. Counts of 300 specimens of Discoaster and Chiasmolithus in the Nannotetrina quadrata Zone Sample 264A-3-5, $70-71 \mathrm{~cm}$ reveals 73 Discoaster and 227 Chiasmolithus; and in Discoaster sublodoensis Zone Sample 264A-4-5, 60-61 cm, 59 Discoaster and 241 Chiasmolithus. Sample 264A$4-5,60-61 \mathrm{~cm}$ is further distinguished through the domination of the assemblage by three species, Chiasmolithus solitus, C. grandis, and Discoaster sublodoensis.

Some diagnostic species in selected samples are listed below.

Reticulofenestra umbilica Zone

Discoaster saipanensis Subzone

264-2-6, 60-61 cm (34 m):

Chiasmolithus expansus, C. grandis, C. solitus, Coccolithus eopelagicus, C. formosus, C. pelagicus, Discoaster deflandrei, D. nodifer, D. sp. cf. D. saipanensis (small), Helicopontosphaera sp. cf. H. reticulata, Markalius inversus, Reticulofenestra samodurovi, R. umbilica, Rinabdosphaera tenuis? (stems), Sphenolithus 


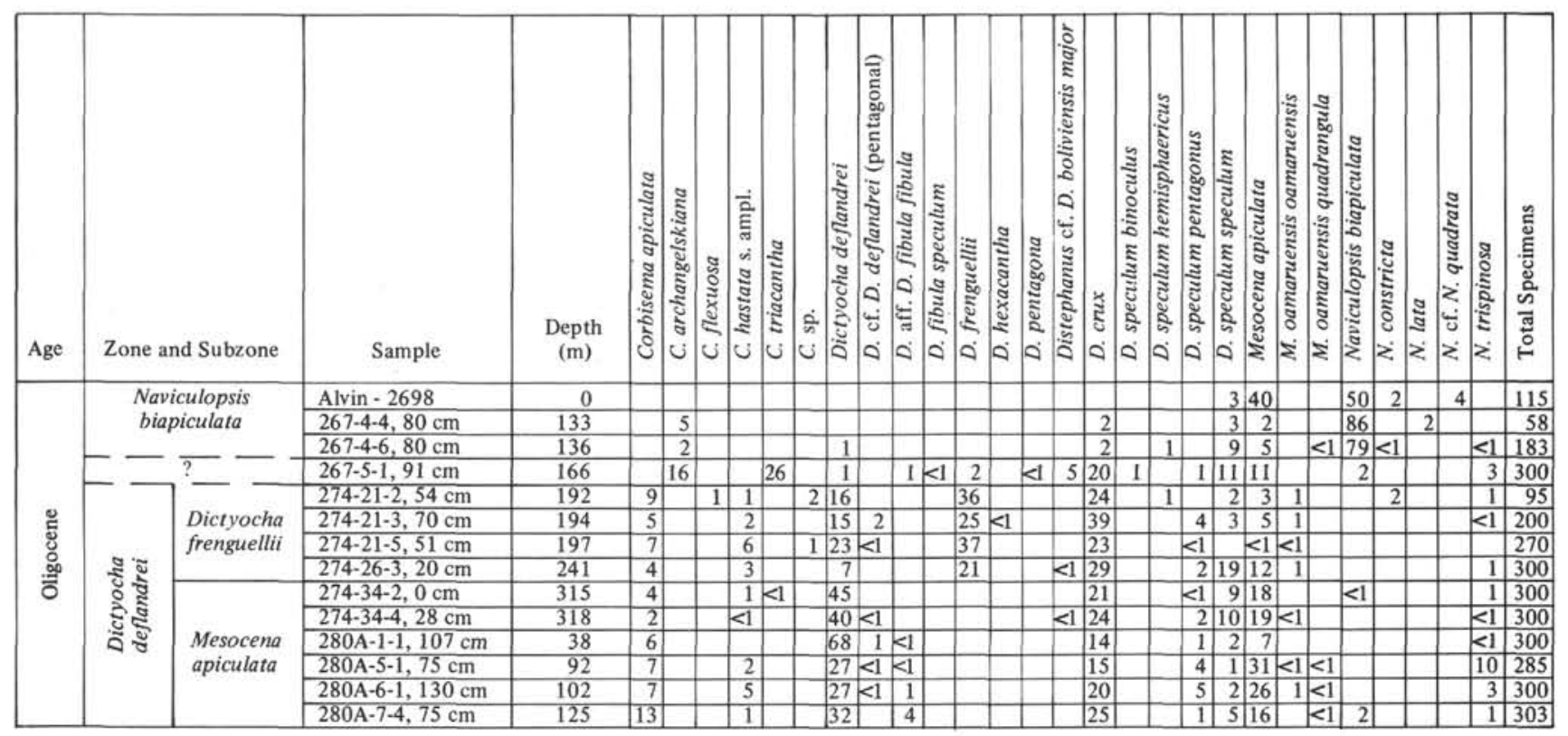

Figure 3. Occurrence of silicoflagellates in deep-sea sediments of Oligocene age. Abundances recorded as percent. Alvin-2698 is a late Oligocene reference sample that was collected by the submersible vehicle Alvin in 886 meters of water at lat. $40^{\circ}$ $15^{\prime} \mathrm{N}$ long. $68^{\circ} 06^{\prime} \mathrm{W}$. Dictyocha frenguellii Subzone and Mesocena apiculata Subzone are new subzones of the Dictyocha deflandrei Zone.

moriformis, S. obtusus, Thoracosphaera sp., Zygolithus minutus, Zygrhablithus bijugatus.

\section{Reticulofenestra umbilica Zone, Discoaster bifax Subzone}

264-3-6, 60-61 cm (62 m):

Chiasmolithus grandis, C. solitus, Coccolithus formosus, C. pelagicus, Cyclicargolithus pseudogammation, Discoaster barbadiensis, D. bifax, D. deflandrei, D. septemradiatus, Markalius inversus, Reticulofenestra samodurovi, $R$. sp. cf. $R$. umbilica, Rhabdosphaera tenuis? (stems), Zygolithus minutus, Zygrhablithus bijugatus.

\section{Nannotetrina quadrata Zone}

264A-3-5, 70-71 cm (147 m):

Chiasmolithus grandis, C. solitus, Coccolithus formosus, C. pelagicus, Cyclicargolithus pseudogammation, Cyclolithella bramlettei, Discoaster barbadiensis (small), $D$. sp. cf. D. deflandrei, D. sp. cf. D. septemradiatus, Nannotetrina alata, $N$. cristata, Reticulofenestra samodurovi, Sphenolithus radians, Triquetrorhabdulus inversus, Zygolithus dubius, Zygrhablithus bijugatus.

Discoaster sublodoensis Zone,

Rhabdosphaera inflata Subzone?

264A-4-5, 60-61 cm (155 m):

Chiasmolithus grandis, C. solitus, Coccolithus eopelagicus, C. pelagicus, Cyclicargolithus pseudogammation, Discoaster barbadiensis, D. sublodoensis, Ellipsolithus lajollaensis, Nannotetrina cristata, Reticulofenestra dictyoda, Sphenolithus sp. cf. S. moriformis, Triquetrorhabdulus inversus, Zygolithus dubius.

Discoaster sublodoensis Zone,

Discoasteroides kuepperi Subzone

264-10-3, 82-83 cm (162 m):

Chiasmolithus grandis, C. solitus, Coccolithus formosus, C. magnicrassus, C. pelagicus, Cyclicargolithus pseudogammation, Cyclococcolithina gammation, Discoaster barbadiensis, D. sp. cf. D. lodoensis, D. sublodoensis, Reticulofenestra dictyoda, Sphenolithus radians, Zygolithus dubius, Zygrhablithus bijugatus.

Abundant Late Cretaceous coccoliths of the Santonian or early Campanian Gartnerago obliquum Zone occur in samples from Core 11. The assemblages are quite diverse and should yield many species in electronmicroscope study. Light-microscope examination reveals no specimens of Marthasterites furcatus or Broinsonia parca, guide fossils to adjacent zones. Species present include Amphizygus brooksii brooksii, Arkhangelskiella cymbiformis, Biscutum spp., Broinsonia bevieri, Chiastozygus sp., Cretarhabdus crenulatus, Cribrosphaera ehrenbergii, Eiffellithus augustus, E. turriseiffelli, Gartnerago costatum costatum, Kamptnerius magnificus, Micula decussata, Parhabdolithus sp., Prediscosphaera cretacea, Similicoronilithus primus? (both shields birefringent), Tetralithus pyramidus, Vagalapilla sp., Watznaueria barnesae, Zygodiscus bicrescenticus, $Z$. spp. The hole terminated in barren basaltic conglomerate.

\section{Site 265 (lat $53^{\circ} 32.45^{\prime} \mathrm{S}$, long $109^{\circ} 56.74^{\prime} \mathrm{E}$, depth $3582 \mathrm{~m}$ )}

Site 265 is about $500 \mathrm{~km}$ south of the crest of the Southeast Indian Ridge. Coccoliths are absent or, where present, provide only broad age assignments. Placoliths dominate assemblages. Key stratigraphic species for low-latitude zonation occur only rarely. For example, single specimens of Gephyrocapsa oceanica in Sample 265-2-6, 76-77 cm and Catinaster calyculus, Discoaster brouweri, and Triquetrorhabdulus rugosus in Sample 265$15-6,80-81 \mathrm{~cm}$ provide the bases for restricted age determinations.

Silicoflagellate abundance is variable, and assemblages are dominated by the cold-water taxon Distephanus speculum speculum. For example, a count of 
300 specimens in late Miocene or early Pliocene Sample 265-14-6, 20-21 cm shows 95\% Distephanus speculum speculum and only $1 \%$ or less than $1 \%$ each for Dictyocha aspera, D. fibula, D. pseudofibula, Distephanus crux, D. speculum binoculus, $D$. speculum pentagonus, $D$. speculum speculum (symmetric variant having small apical ring), and Mesocena sp. cf. M. diodon. A paleotemperature below $5^{\circ} \mathrm{C}$ is indicated by the predominance of Distephanus according to the silicoflagellate paleotemperature curve of Mandra (1969). This approximates present Antarctic and Subantarctic water temperatures.

\section{Site 266 (lat $56^{\circ} 24.13$ 'S, long $110^{\circ} 06.70^{\prime} \mathrm{E}$, depth $4173 \mathrm{~m}$ )}

Site 266 is about $800 \mathrm{~km}$ south of the crest of the Southeast Indian Ridge. Upper Cores 1 to $11(0-168 \mathrm{~m})$ are barren of coccoliths or have assemblages that are poorly diagnostic for age. There is an extensive lower middle Miocene to lower Miocene section represented in samples from Cores 12 to $23(177-375 \mathrm{~m})$ by mixed phytoplankton assemblages of coccoliths, diatoms, and silicoflagellates. Many species present at Site 266 are known from the eastern Pacific near California. For example, Sample 266-18-1, 120-121 cm contains the diatom Raphidodiscus marylandicus and an unusual variety of silicoflagellate resembling Distephanus schauinslandii that is known only from the Helicopontosphaera ampliaperta Zone in California.

The early middle Miocene age of Core 14 , Section 4 is indicated by the presence of Sphenolithus heteromorphus, Cyclococcolithina macintyrei s. ampl., and Coscinodiscus lewisianus. The assemblages of Core 12, Section 5; Core 13, Section 4, and Core 13, Section 6 are less definitive, but the overlap of Coccolithus miopelagicus, Cyclicargolithus floridanus, and Cyclococcolithina macintyrei s. ampl. indicates an early middle Miocene age.

Zonation is impeded in Core 18 , Section 5 to Core 23, Section 1 by the low diversity of coccoliths and rare occurrence of silicoflagellates. The coccolith genera Sphenolithus, Helicopontosphaera, Coronocyclus, Triquetrorhabdulus, and Orthorhabdus, which aid zonation in low-latitude and less-dissolved assemblages, are essentially absent. Instead, the assemblages are dominated by the cool-water discoaster $D$. deflandrei and by the placoliths Coccolithus miopelagicus, C. pelagicus, Cyclicargolithus bukryi, C. floridanus, and Reticulofenestra gartneri s. ampl. Domination of assemblages by one species, C. miopelagicus in Core 22, two species, $C$. floridanus and $D$. deflandrei in Core 19 , is typical of high-latitude or cool-water environments.

Although silicoflagellates are rare, generally less than 20 specimens per smear slide, the composite array of species indicates a latest Oligocene to early middle Miocene range. Species identified include Corbisema triacantha, Distephanus crux, D. speculum speculum, Mesocena circulus, M. pappii, Naviculopsis biapiculata, $N$. constricta, $N$. lata, $N$. sp. cf. $N$. quadrata, and Rocella gemma. The specimens of $M$. pappii in Core 19, Section 6; Core 20, Section 4; Core 21, Section 4; and Core 21,
Section 6 are the first representatives of this species observed in DSDP cores. The triangular body ring is smooth and has two diverging distal spines at each apex.

\section{Site 267 (lat $59^{\circ} 15.74^{\prime} \mathrm{S}$, long $104^{\circ} 29.30^{\prime} \mathrm{E}$, depth $4564 \mathrm{~m}$ )}

Site 267 is located in a basin south of the Southeast Indian Ridge. Samples from Cores 1 to $3(0-99 \mathrm{~m})$ lack coccoliths. Cores 4 to $5(128-175 \mathrm{~m})$ contain coccoliths and silicoflagellates of Oligocene age. The cool-water assemblages constituting the etched placolith ooze have only rare Discoaster deflandrei and D. nodifer?, and, typically, lack Helicopontosphaera and Sphenolithus. The assemblage of Sample 267-4-6, 80-81 cm (136 m) is dominated by Cyclicargolithus floridanus but contains Chiasmolithus altus, Coccolithus eopelagicus, Dictyococcites bisectus, D. scrippsae, Isthmolithus recurvus (reworked), and Reticulofenestra sp.

Whereas the coccolith assemblages of Core 4 suggest only a general Oligocene age, silicoflagellate assemblages (Figure 3) suggest a late Oligocene age. The domination of Naviculopsis biapiculata and the diatom Coscinodiscus vigilans in the absence of Dictyocha deflandrei distinguish the assemblages of Core 4 from those of the early Oligocene. Although $C$. vigilans structurally resembles Rocella gemma, no unquestioned specimens of $R$. gemma, a late Oligocene marker species, were observed.

Core 5 contains enigmatic assemblages of silicoflagellates that have no known correlative. Coccolith assemblages are so etched and restricted in diversity that only a general Oligocene age could be inferred. For example, silicoflagellates of Sample 267-5-1, 91-92 $\mathrm{cm}(166 \mathrm{~m})$ are recorded in Figure 3; coccoliths present include only Chiasmolithus altus, Coccolithus miopelagicus, C. pelagicus, Cyclicargolithus abisectus?, C. floridanus, Dictyococcites bisectus, Reticulofenestra sp., and Sphenolithus moriformis. Although the definite identification of $C$. abisectus would assure a late Oligocene age, poor preservation limits the confidence of the identification.

Two samples from Core $6(204-210 \mathrm{~m})$, both just above basalt, contain etched, low-diversity coccolith assemblages that are considered late Eocene or early early Oligocene on the basis of the presence of Chiasmolithus expansus, Dictyococcites bisectus, and Reticulofenestra hillae. Other species present include Coccolithus eopelagicus, C. pelagicus, Cyclicargolithus floridanus, Discoaster deflandrei, and Sphenolithus moriformis. The absence of solution-resistant Coccolithus formosus, which is common in low-latitude samples of this age, and its rarity below are further evidence for cool-water deposition at this site.

The oldest samples available are late Eocene coccolith ooze from Sample 267B-10-1 (314-323 m). The common occurrence of Isthmolithus recurvus and the great abundance of the Chiasmolithus species C. altus, C. expansus, and $C$. oamaruensis indicate cool-water deposition as well as a late Eocene age. Other species present include Coccolithus eopelagicus, $C$. formosus (trace), C. sp. cf. $C$. obrutus, C. pelagicus, Dictyococcites bisectus, Reticulofenestra hillae, and $R$. umbilica. 
The specimens of Isthmolithus recurvus, a species thought to have evolved from late middle Eocene Zygolithus minutus (M. N. Bramlette, personal communication, 1971), show fully developed species characteristics. Many specimens, however, have lost their rhomboid outline and three central openings as a result of overgrowth by secondary calcite. Similar forms have been illustrated as Isthmolithus triplus Levin and Joerger (1967). Discriminating stratigraphically useful taxa from redundant synonyms, described from overgrown (or etched) specimens, is aided by samples such as these wherein a range of overgrowth stages is preserved together (Bukry et al., 1973).

\section{Site 268 (lat $63^{\circ} 56.99^{\prime} \mathrm{S}$, long $105^{\circ} 09.34^{\prime} \mathrm{E}$, depth $3544 \mathrm{~m}$ )}

Site 268 is on the lower continental rise north of the Knox Coast of Antarctica. Only two samples with abundant coccoliths were studied from Site 268; other samples are barren or contain only one or two specimens. Sample 268-10-1, 20-21 cm (228 m) contains an ooze of the genus Coccolithus. In addition to the two dominant species, Coccolithus miopelagicus and $C$. pelagicus, only Discoaster sp. cf. D. deflandrei and small Reticulofenestra sp. have been identified. Similar assemblages were encountered in the more fossiliferous early Miocene at Site 266, Core 22. Although silicoflagellates are rare in 268-10-1, the occurrence of Mesocena pappii with $M$. apiculata and Distephanus speculum suggests correlation with the early Miocene of Site 266.

Sample 268-17-3, 9-10 cm $(381 \mathrm{~m})$ contains a coolwater placolith ooze that has been strongly etched. The occurrence of both Chiasmolithus altus and Dictyococcites bisectus suggests an age no later than Oligocene. The lack of Reticulofenestra hillae or $R$. umbilica suggests that the sample is younger than early Oligocene.

\section{Site 269 (lat $61^{\circ} 40.57^{\prime} \mathrm{S}$, long $140^{\circ} 04.21^{\prime} \mathrm{E}$, depth $4285 \mathrm{~m}$ )}

Site 269 is on the abyssal plain between the mid-ocean ridge and the continental rise north of the Wilkes Land Coast of Antarctica. Samples from Cores 1 to 11 are barren of coccoliths except for a few specimens of nondiagnostic Reticulofenestra sp. occurring in Sample 269$7-3,110-111 \mathrm{~cm}(235 \mathrm{~m})$. The only significant coccolith sample available at this site is Sample 269A-12-5, 72-73 $\mathrm{cm}(908 \mathrm{~m})$. Even there, the coccolith assemblage is poorly diagnostic. The association of Coccolithus miopelagicus, C. pelagicus, Cyclicargolithus abisectus, $C$. floridanus, Dictyococcites sp. cf. D. bisectus, Discolithina sp., Reticulofenestra sp., and Sphenolithus moriformis suggests an earliest Miocene age.

\section{Site 270 (lat $77^{\circ} 26.48$ 'S, long $178^{\circ} 30.19^{\prime} \mathrm{W}$, depth $634 \mathrm{~m}$ )}

Three samples examined from this site in the southeastern part of the Ross Sea are barren of coccoliths.

\footnotetext{
Site 271 (lat $76^{\circ} 43.27^{\prime} \mathrm{S}$, long $175^{\circ} 02.86^{\prime} \mathrm{W}$, depth $554 \mathrm{~m}$ )

No samples available; see reports of shipboard scientists.
}

Site 272 (lat $77^{\circ} 07.62^{\prime} \mathrm{S}$, long $176^{\circ} 45.61^{\prime} \mathrm{W}$, depth $629 \mathrm{~m}$ )

No samples available; see reports of shipboard scientists.

Site $273\left(7^{\circ} 32.29^{\prime} \mathrm{S}\right.$, long $174^{\circ} 37.57^{\prime} \mathrm{E}$, depth $\left.495 \mathrm{~m}\right)$

No samples available; see reports of shipboard scientists.

Site 274 (lat $68^{\circ} 59.81^{\prime} \mathrm{S}$, long $173^{\circ} 25.64^{\prime} \mathrm{E}$, depth $3326 \mathrm{~m}$ )

Site 274 is north of the Ross Sea and south of the midocean ridge. Samples from diatom-rich Oligocene Cores 20 to $34(181-323 \mathrm{~m})$ were examined for coccoliths and silicoflagellates. Coccolith occurrences are limited to Core 21 , but silicoflagellates are common throughout the sequence. The silicoflagellate assemblages (Figure 3) and diatom assemblages are easily correlative with those at Hole $280 \mathrm{~A}$, located north of the mid-ocean ridge south of Tasmania.

The low-diversity coccolith assemblages of Core 21 (192-197 m) are probably late Oligocene, on the basis of the presence of Chiasmolithus altus, $C$. sp. cf. C. oamaruensis, Coccolithus pelagicus, Dictyococcites scrippsae, and Reticulofenestra sp.

The silicoflagellate assemblages, assigned to the early or late Oligocene Dictyocha deflandrei Zone, are dominated by Dictyocha deflandrei, Distephanus crux, and Mesocena apiculata. The upper part of the section (Cores 21-26) is distinguished by an abundant occurrence of Dictyocha frenguellii. This species is absent in the lower part of the section and is missing from the D. deflandrei Zone assemblages in Hole 280A.

\section{REFERENCES}

Bachmann, A., 1970. Silicoflagellaten aus dem oberösterreichischen Egerien (Oberoligozän): Österreich Geol. Bundesanst. Verhandl., v. 2, p. 275-305.

Bukry, D., 1973. Low-latitude coccolith biostratigraphic zonation: In Edgar, N. T., Saunders, J. B., et al., Initial Reports of the Deep Sea Drilling Project, Volume 15: Washington (U.S. Government Printing Office), p. 685703.

Bukry, D. and Foster, J. H., 1974. Silicoflagellate zonation of Upper Cretaceous to lower Miocene deep-sea sediment: U.S. Geol. Surv. J. Res., v. 2, no. 3, p. 303-310.

Bukry, D., Dinkelman, M. G., and Kaneps, A., 1973. Biostratigraphy of the equatorial East Pacific Rise: In van Andel, Tj. H., Heath, G. R., et al., Initial Reports of the Deep Sea Drilling Project, Volume 16: Washington (U.S. Government Printing Office), p. 915-935.

Čepek, P. and Hay, W. W., 1969. Calcareous nannoplankton and biostratigraphic subdivision of the Upper Cretaceous: Gulf Coast Assoc. Geol. Soc. Trans., v. 19, p. 323-336.

Dumitricǎ, P., 1973. Paleocene, late Oligocene and postOligocene silicoflagellates in southwestern Pacific sediments cored on DSDP Leg 21. In Burns, R. E., Andrews, J. E., et al., Initial Reports of the Deep Sea Drilling Project Volume 21: Washington (U.S. Government Printing Office), p. 837-883.

Glezer, Z. I., 1966. Silicoflagellatophyceae. In Gollerbakh, M. M. (Ed.), Cryptogamic plants of the U.S.S.R.: Akad. Nauk SSSR, V. A. Komarova Bot. Inst. (Translated from Russian by Israel Program for Scientific Translations Ltd., Jerusalem, 1970), v. 7, p. 1-363. 
Levin, H. L. and Joérger, A. P., 1967. Calcareous nannoplankton from the Tertiary of Alabama: Micropaleontology, v. 13, p. 163-182.

Ling, H. Y., 1972. Upper Cretaceous and Cenozoic silicoflagellates and ebridians: Am. Paleontol. Bull., v. 62, p. 135-229.

Loeblich, A. R., 3d, Loeblich, L. A., Tappan, H., and Loeblich, A. R., Jr., 1968. Annoted index of fossil and recent silicoflagellates and ebridians with descriptions and illustrations of validly proposed taxa: Geol. Soc. Am. Mem. 106.

Mandra, Y. T., 1969. Silicoflagellates: A new tool for the study of Antarctic Tertiary climates: U.S. Antarctic J., v. 4, p. 172-174.
Mandra, Y. T., Brigger, A. L., and Mandra, H., 1973, Preliminary report on a study of fossil silicoflagellates from Oamaru, New Zealand: Calif. Acad. Sci. Occasional Papers no. 107 , p. $1-11$.

Martini, E., 1972. Silicoflagellate zones in the late Oligocene and early Miocene of Europe: Senckenb. Lethaea, v. 53, p. 119-122.

Roth, P. H., 1973. Calcareous nannofossils-Leg 17, Deep Sea Drilling Project: In Winterer, E. L., Ewing, J. I., et al., Initial Reports of the Deep Sea Drilling Project Volume 17: Washington (U.S. Government Printing Office), p. 695795. 


\section{PLATE 1}

Silicoflagellates from Leg 28.

Figures 1-6, 8-12 magnification $800 \times$; scale bar equals $10 \mu$.

Figure 7 magnification $1000 \times$; scale bar equals $10 \mu$.

Figure $1 \quad$ Corbisema apiculata (Lemmermann);

Sample 274-21-5, $51 \mathrm{~cm}(197 \mathrm{~m})$.

Figures 2, 3 Corbisema sp. cf. C. archangelskiana (Schulz);

Sample 267-5-1, $91 \mathrm{~cm}(166 \mathrm{~m})$.

2. High focus.

3. Low focus.

Figure 4 Corbisema sp. cf. C. hastata hastata (Lemmermann);

Sample 274-21-5, $51 \mathrm{~cm}(197 \mathrm{~m})$.

Figure $5 \quad$ Corbisema hastata minor (Schulz);

Sample 274-21-5, $51 \mathrm{~cm}(197 \mathrm{~m})$.

Figure $6 \quad$ Corbisema triacantha (Ehrenberg);

Sample 267-5-1, $91 \mathrm{~cm}(166 \mathrm{~m})$.

Figures 7-10 Dictyocha deflandrei Frenguelli ex Glezer.

7. Sample $274-21-3,70 \mathrm{~cm}(194 \mathrm{~m})$.

8. Sample $274-34-4,28 \mathrm{~cm}(318 \mathrm{~m})$.

9. Sample $274-21-5,51 \mathrm{~cm}(197 \mathrm{~m})$.

10. Sample 274-21-2, $54 \mathrm{~cm}(192 \mathrm{~m})$.

Figures 11-12 Dictyocha frenguellii Deflandre;

Sample 274-21-5, $51 \mathrm{~cm}$ (197 m).

11. Low focus.

12. High focus. 
PLATE 1
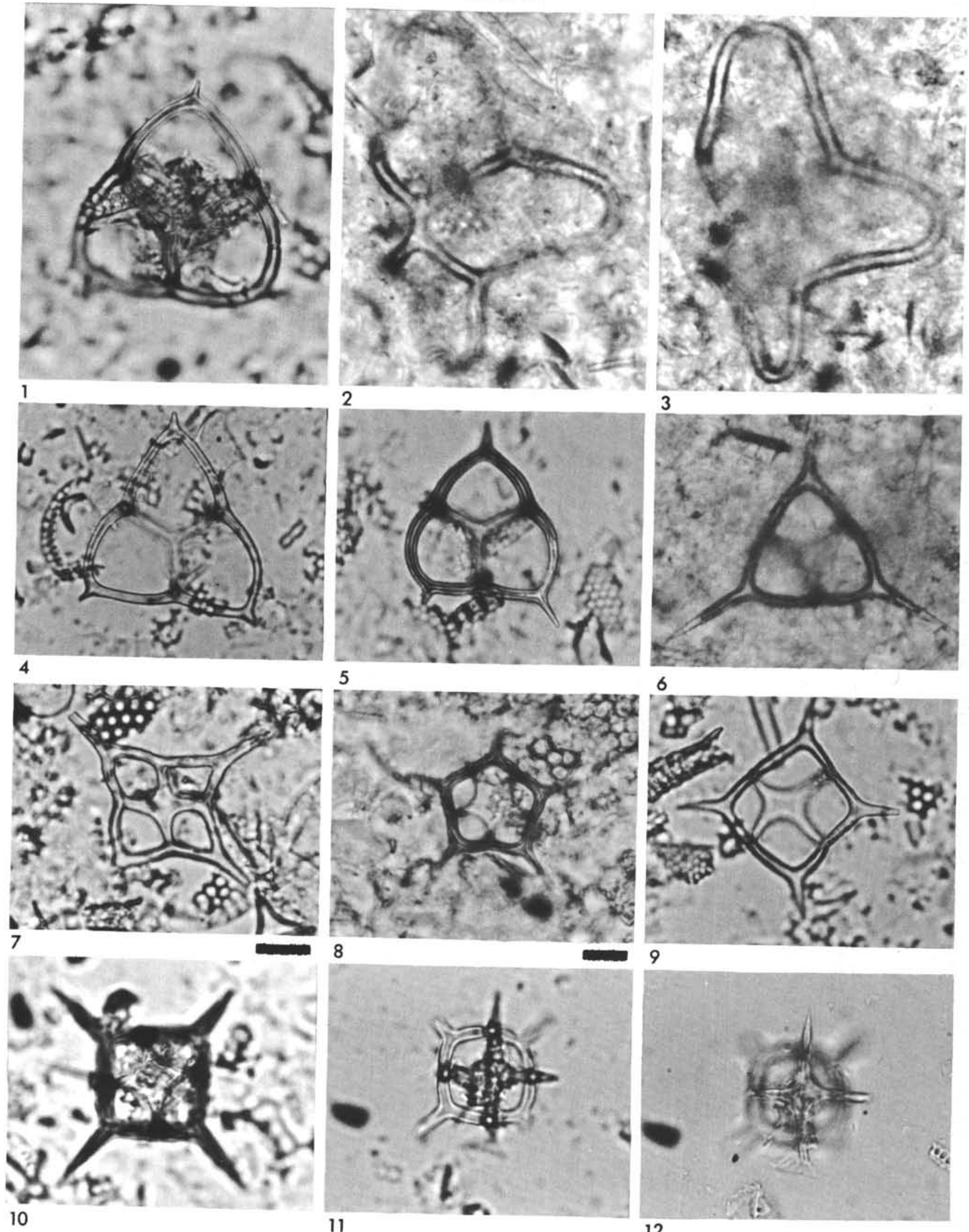


\section{PLATE 2}

Silicoflagellates from Leg 28 and Southern California Borderland.

Magnification $800 \times$; scale bar equals $10 \mu$.

Figure 1 Distephanus crux crux (Ehrenberg); Sample 274-21-5, $51 \mathrm{~cm}(197 \mathrm{~m})$.

Figures 2, 3 Distephanus crux hannai Bukry.

2. Sample $266-17-1,110 \mathrm{~cm}(254 \mathrm{~m})$.

3. Sample Kelez 73100227 (lat $33^{\circ} 24^{\prime} \mathrm{N}$, long $\left.119^{\circ} 03^{\prime} \mathrm{W}\right)$.

Figures 4-5 Mesocena circulus (Ehrenberg);

Sample 266-23-1, $29 \mathrm{~cm}(370 \mathrm{~m})$.

Figure $6 \quad$ Mesocena sp. cf. M. elliptica (Ehrenberg);

Sample 266-23-1, $29 \mathrm{~cm}$ (370 m).

Figure 7 Mesocena pappii Bachmann;

Sample 266-20-4, $70 \mathrm{~cm}(315 \mathrm{~m})$. 
PLATE 2
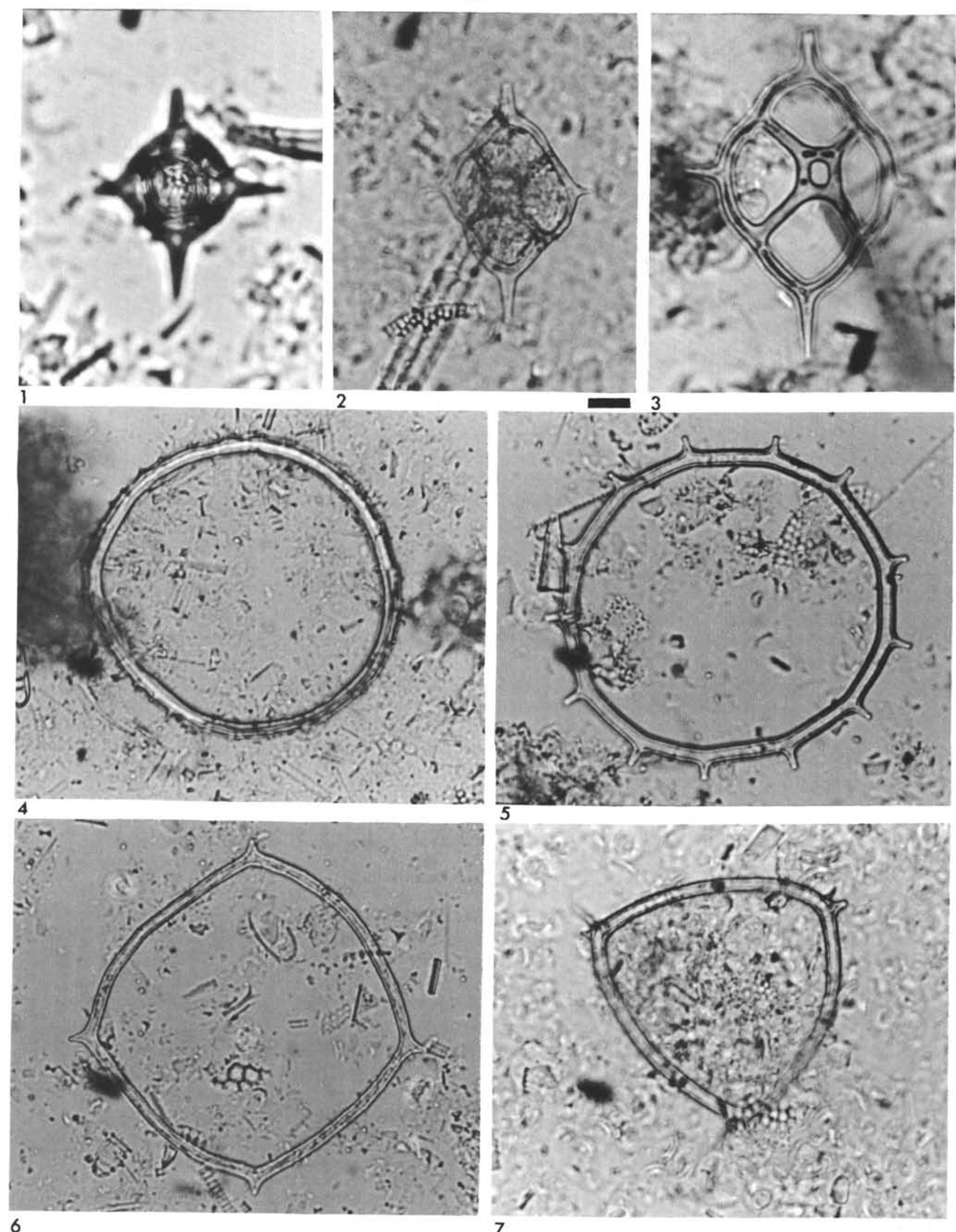


\section{PLATE 3}

Silicoflagellates and diatom from Leg 28.

Magnification $800 \times$; scale bar equals $10 \mu$.

Figure 1

Figure 2

Figure 3

Figure 4

Figure 5
Mesocena pappii Bachmann;

Sample 266-21-6, $70 \mathrm{~cm}$ (337 m).

Naviculopsis biapiculata (Lemmermann);

Sample 267-5-1, $91 \mathrm{~cm}$ (166 m).

Naviculopsis sp. cf. N. quadrata (Ehrenberg);

Sample 266-21-6, $70 \mathrm{~cm}(337 \mathrm{~m})$.

Corbisema archangelskiana (Schulz);

Sample 267-4-6, $80 \mathrm{~cm}$ (136 m).

Coscinodiscus lewisianus Greville; characteristic early Miocene diatom; Sample 266-23-1, $29 \mathrm{~cm}$ $(370 \mathrm{~m})$. 
PLATE 3

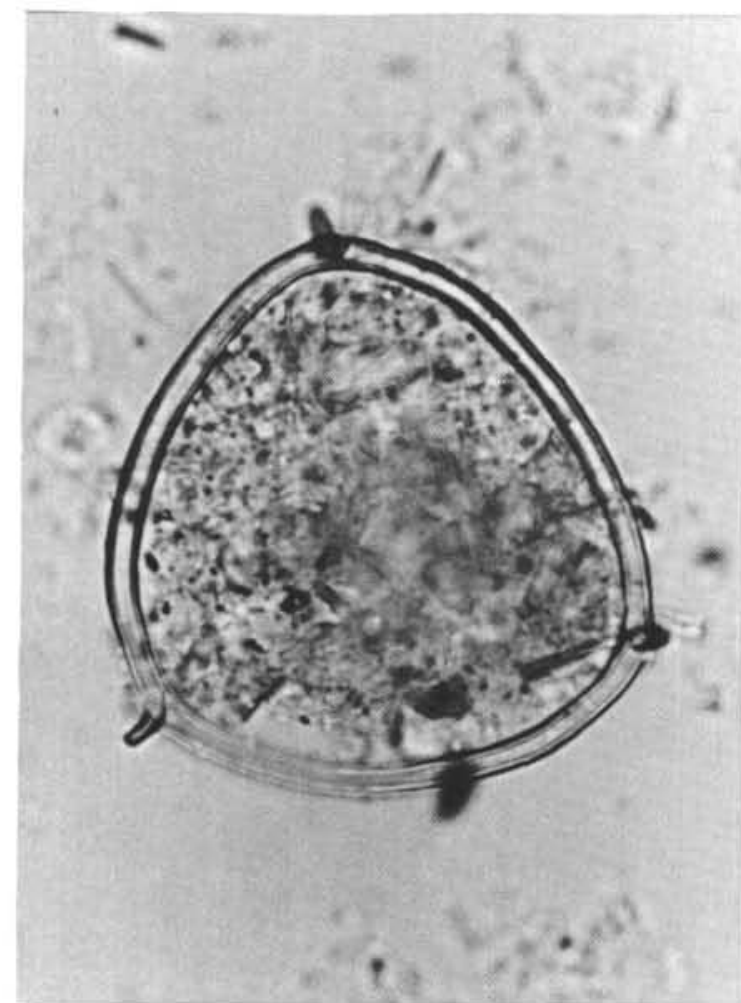

\section{1}

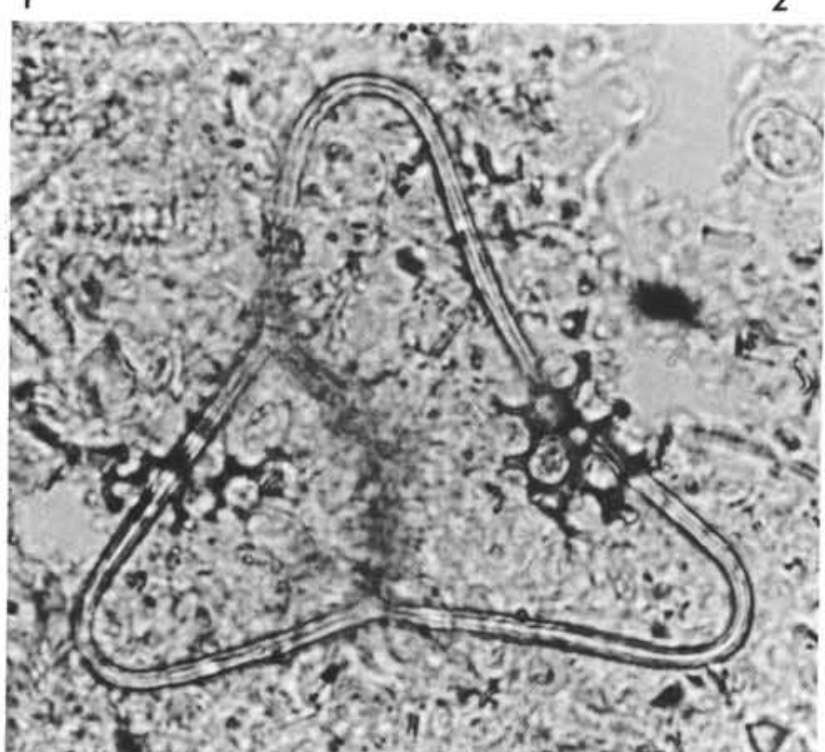

4
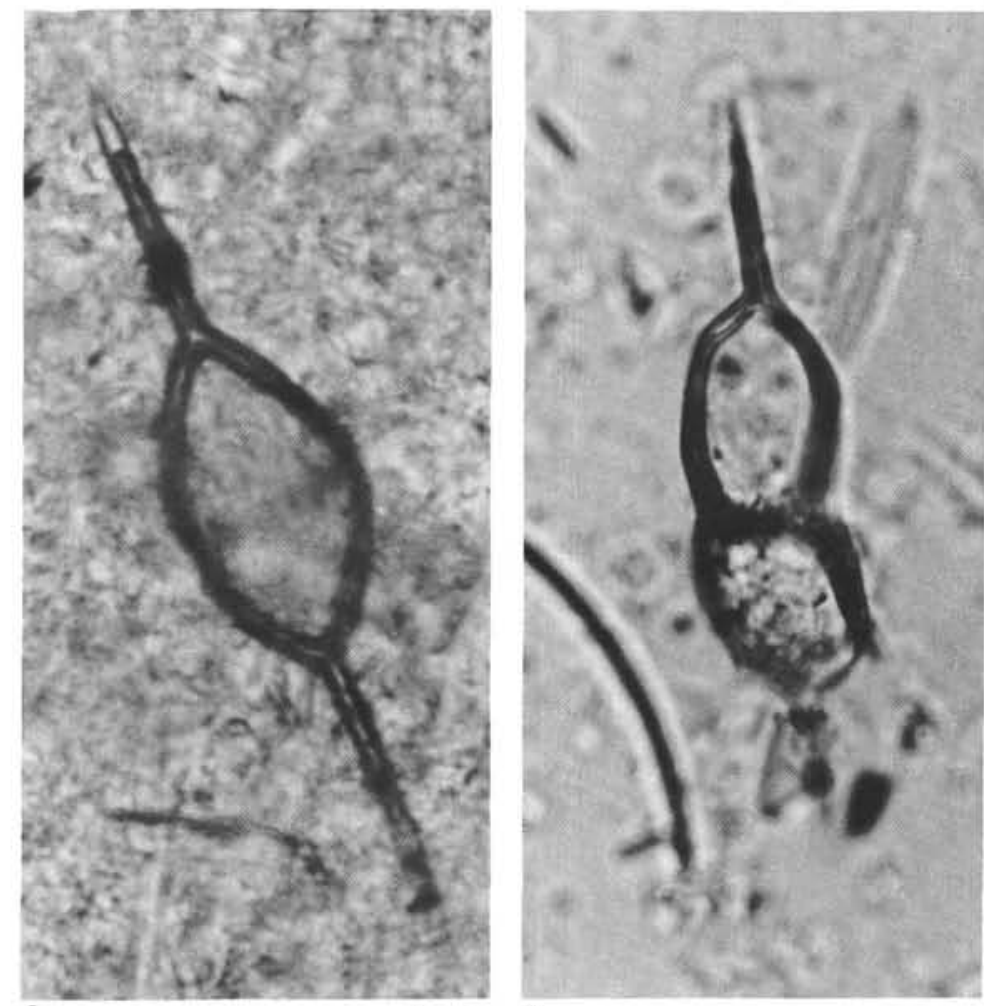

3

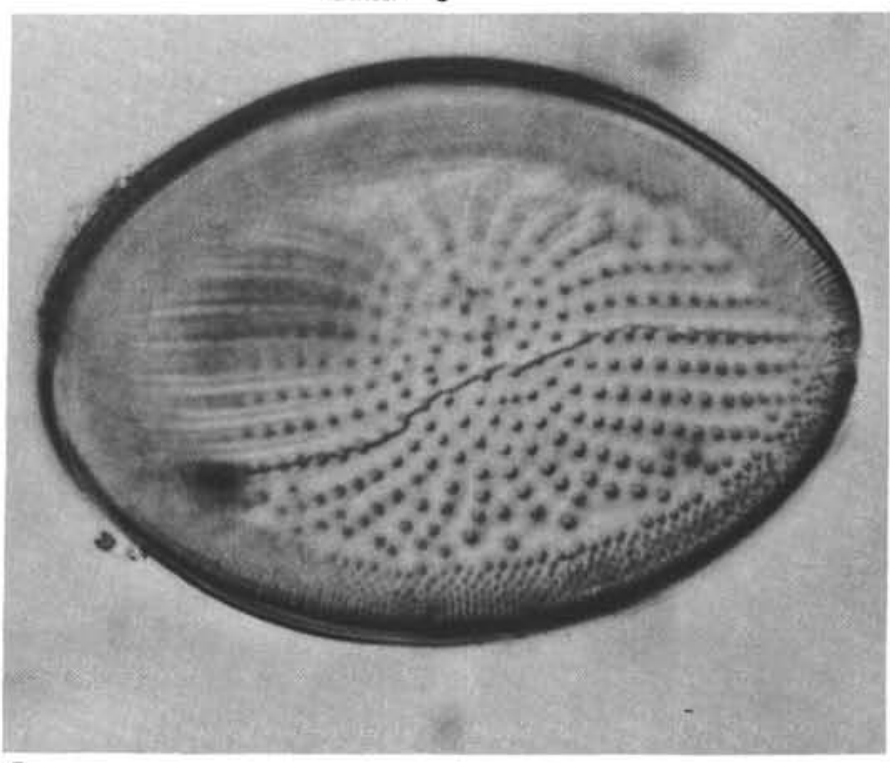




\section{PLATE 4}

Possible origin of the problematic silicoflagellate Rocella gemma Hanna from the Diatom Coscinodiscus vigilans Schmidt shown by Specimens from Leg 28, Leg 29, and from Scripps Core JYN-V-16P (lat $7^{\circ} 44^{\prime} \mathrm{N}$, long $149^{\circ} 44^{\prime} \mathrm{W}$ ). Compare central pore, peripheral structure, and size distribution of perforations. Magnification $800 \times$; scale bar equals $10 \mu$.

Figures 1-3 Coscinodiscus vigilans Schmidt.

1. Sample 267-4-6, $80 \mathrm{~cm}(136 \mathrm{~m})$.

2,3. Sample $278-31-2,75 \mathrm{~cm}(397 \mathrm{~m})$.

Figures 4-6 Coscinodiscus sp. cf. C. vigilans Schmidt.

4. Sample $266-21-4,73 \mathrm{~cm}(334 \mathrm{~m})$.

5,6 . Sample $278-31-2,75 \mathrm{~cm}(397 \mathrm{~m})$.

Figures 7-9 Rocella gemma Hanna.

7. Sample $278-10-5,75 \mathrm{~cm}(184 \mathrm{~m})$.

8,9 . Sample JYN-V-16P, $1 \mathrm{~cm}(0 \mathrm{~m})$. 
PLATE 4

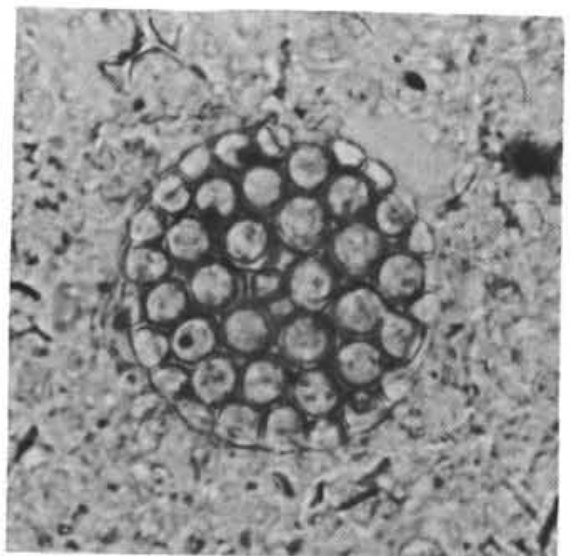

1 -

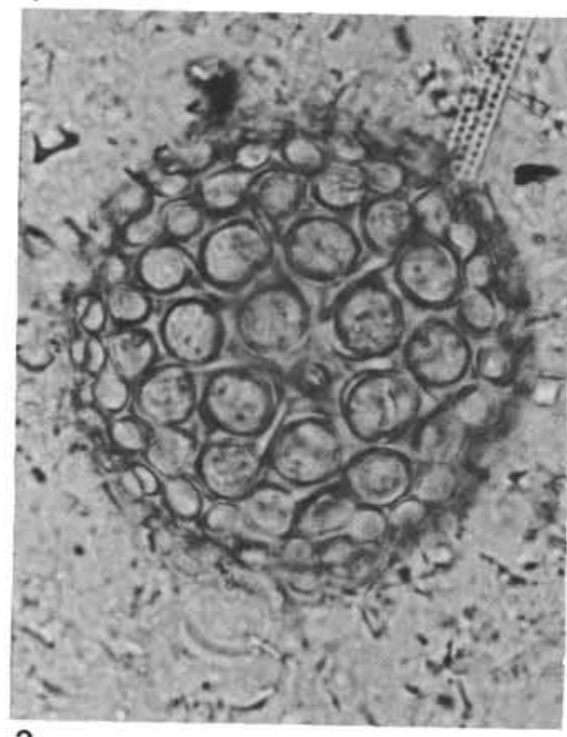

2

-

$7 x^{2}+5 \times 2$

1.50

alo 1000

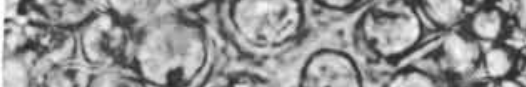

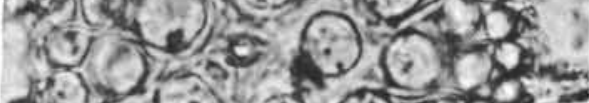

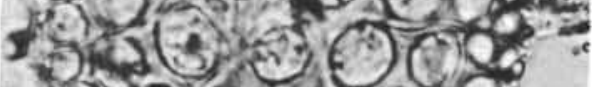

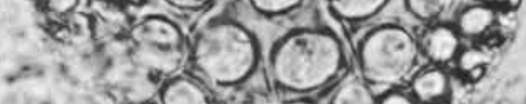

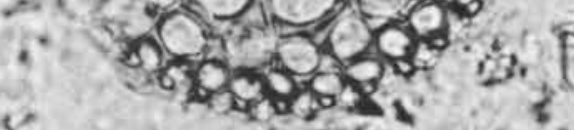

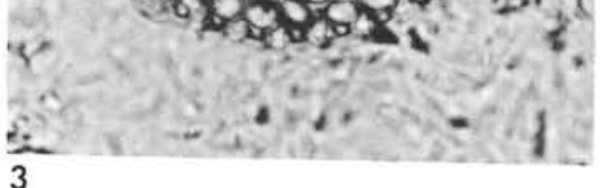

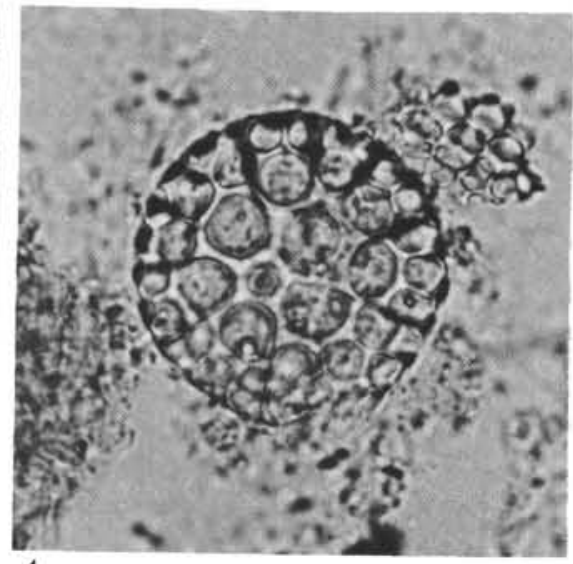

4
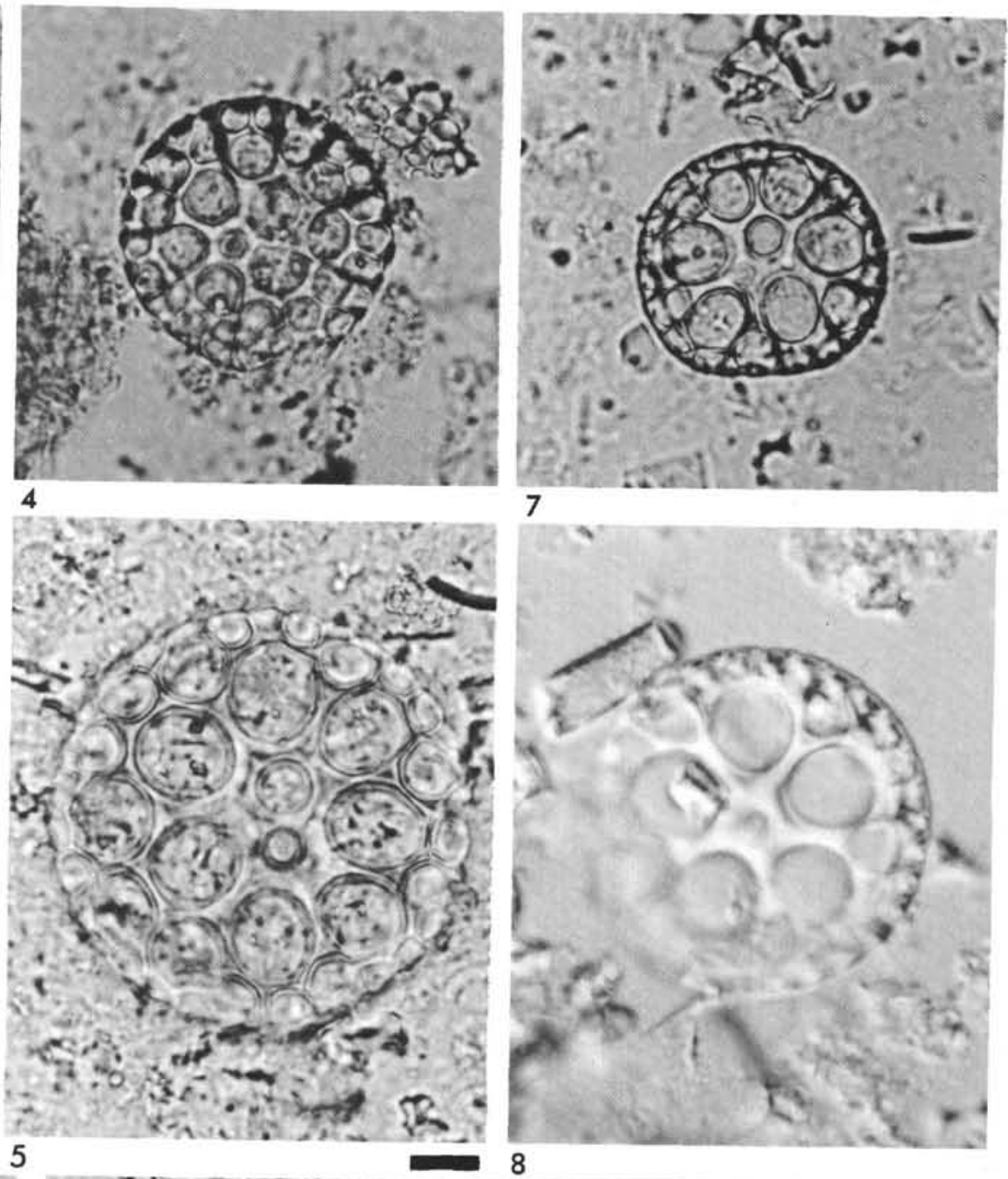

7

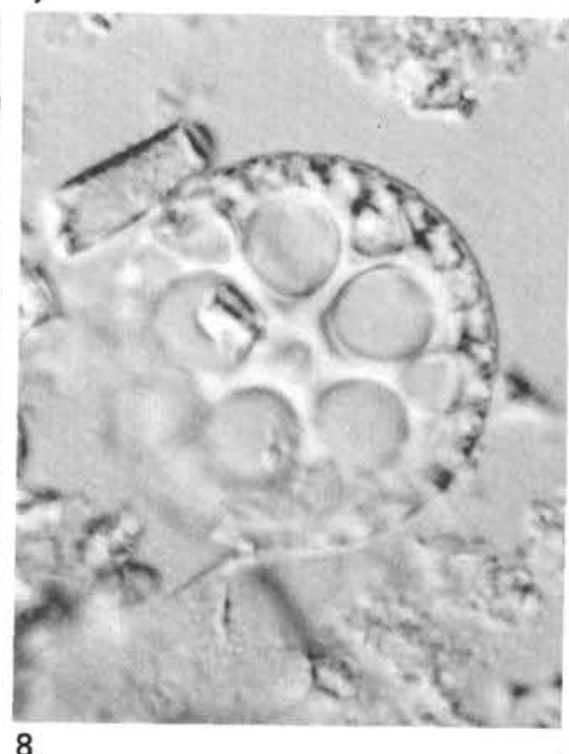

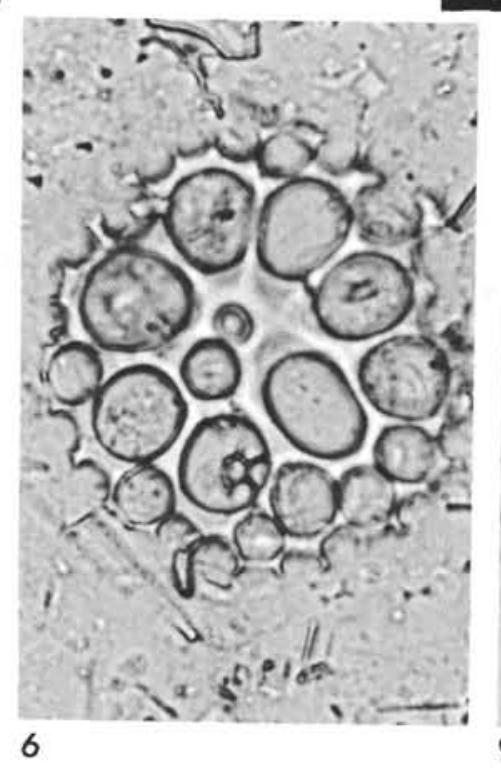

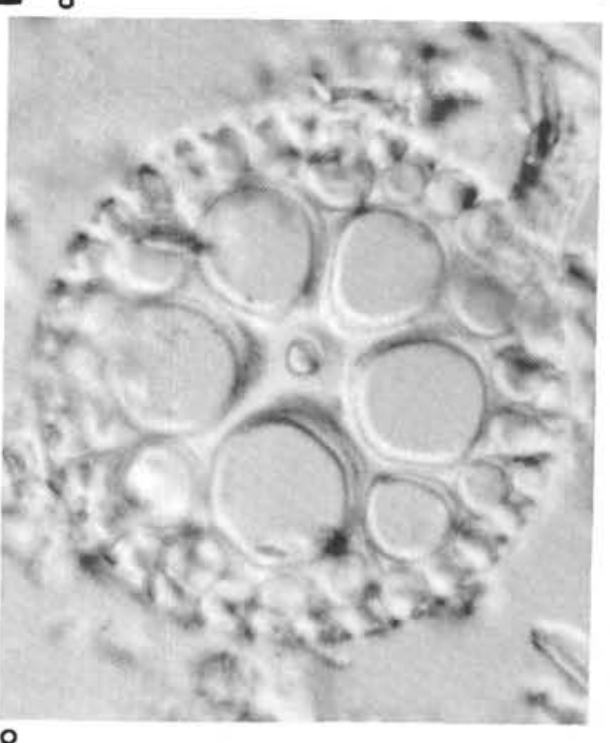

